\title{
Eastward moult migration of non-breeding pink-footed geese (Anser brachyrhynchus) in Svalbard
}

\author{
Christian M. Glahder, ${ }^{1}$ Anthony D. Fox, ${ }^{2}$ Mark O'Connell, ${ }^{3}$ Martin Jespersen ${ }^{1}$ \& Jesper Madsen ${ }^{1}$ \\ 1 National Environmental Research Institute, University of Aarhus, Department of Arctic Environment, Roskilde, Denmark \\ 2 National Environmental Research Institute, University of Aarhus, Department of Wildlife Ecology and Biodiversity, Rønde, Denmark \\ 3 University of West of England, Hartpury, Gloucestershire, UK
}

\section{Keywords}

Anser brachyrhynchus; pink-footed geese; post-breeding; satellite tracking; Svalbard; temperature gradients.

\section{Correspondence}

Christian M. Glahder, National Environmental Research Institute, University of Aarhus, Department of Arctic Environment,

Frederiksborgvej 399, Box 358, DK-4000

Roskilde, Denmark.Email: cmg@dmu.dk

doi:10.1111/j.1751-8369.2007.00006.x

\begin{abstract}
Six adult male pink-footed geese (Anser brachyrhynchus), tagged with satellite transmitters, were tracked in Svalbard during the period of June-September in 2003 and 2004. The purpose of the study was to describe the movements and staging periods of individual geese during the post-breeding period to investigate a possible moult migration among pink-footed geese in Svalbard. All geese moved about $200 \mathrm{~km}$ east from their potential breeding (summering) areas in western Spitsbergen. The preferred moulting area was the island of Edgeøya, where four geese staged prior to a southward autumn migration. Five geese left potential breeding areas between 11 and 30 June, and remained for more than 25 days in eastern areas during most of July, which we interpret as the moult migration of either failed or non-breeders. Geese left moulting areas in mid-August, using an average of 1.4 staging areas before the autumn migration, suggesting that moult sites support pre-migration hyperphagia. Only one goose remained at the suspected breeding site from early June to early September. Mean monthly temperatures in the summering and moulting ranges of the geese were calculated from Moderate Resolution Imaging Spectroradiometer (MODIS) satellite data. The mean June moult range temperature $\left(-0.9^{\circ} \mathrm{C}\right)$ was significantly lower than that of the summering ranges $\left(4.6^{\circ} \mathrm{C}\right)$. The July mean moult range temperature did not differ significantly from that in June on the summering ranges. We contend that failed or non-breeding pink-footed geese move eastward in Svalbard to exploit the early stages of summer plant growth as a result of the delayed thaw compared with central and southern Spitsbergen.
\end{abstract}

Moult migration in post-breeding waterfowl, first described by Ekman (1922), is a well known event that takes place between the breeding season and the autumn migration. Among goose species it mostly involves subadult birds, but may also include non-breeding and failed breeding birds, and even successful breeders (Hohman et al. 1992). Movements of Palaearctic and Nearctic goose species are in most cases northwards (Salomonsen 1968; Hohman et al. 1992). Exceptions include barnacle geese (Branta leucopsis) in Greenland and probably to some extent greater snow geese (Anser caerulescens atlantica), which move south within their breeding ranges (Madsen et al. 1984; Reed et al. 2003). The migration distance can vary from a few hundred kilometres to more than
$1200 \mathrm{~km}$ in the case of pink-footed geese in Iceland and Greenland (Madsen et al. 1984; Boertmann 1994). There is much speculation as to why geese and other waterfowl undertake a moult migration. Obviously there is an energy cost involved in the movement, but the benefits include access to abundant food resources, protection from predators and refuge from disturbance (Hochbaum 1955; Salomonsen 1968). Food may be restricted on the breeding grounds, as suggested by Madsen \& Mortensen (1987), and because breeders are often behaviourally dominant over non-breeders, there are benefits to the latter if they move to habitats outside the breeding range (Salomonsen 1968; Raveling 1970). In July, more northern habitats support the progressively delayed early 
growth phases of grass and sedge shoots, which have the highest protein content of the annual cycle at this time (Whitten \& Cameron 1980; Davis et al. 1985). Hence, the forage quality in northerly areas with a growth season too short to support breeding birds may offer the springlike early season plant growth that is highly attractive to moulting geese. The Greenland white-fronted goose (Anser albifrons flavirostris) exhibits no marked moult migration, but may take advantage of the progressive development in availability of nutrient-rich food along an altitudinal gradient within the same general summering area (Fox et al. 1983).

In Svalbard there is a west-east temperature gradient that mainly results from the influence of the "warm" North Atlantic current on the west coasts of Svalbard and the "cold" current from Siberia on the eastern Svalbard coastline. Non-breeding pink-footed geese in Svalbard moult within the breeding range (Spitsbergen west of $17^{\circ} \mathrm{E}$ ), and also in the eastern parts of Svalbard mainly on the islands of Edgeøya and Barentsøya (Madsen et al. 1992; Mehlum 1998). According to Mehlum (1998), less than $10 \%$ of the winter population (ca. 30000 in the 1990s; Madsen et al. 1999) were accounted for on Edgeøya and Barentsøya during the period of late July-September.

This paper describes the movements and staging periods of individual pink-footed geese during the breeding and post-breeding period in Svalbard based on data from birds fitted with small satellite transmitters. The geese were tracked from their possible breeding areas in June to their moulting grounds in July and their post-moulting areas prior to the onset of the autumn migration in midSeptember. We test the hypothesis that moulting geese, freed from the association with nest sites and young, undertake a moult migration to areas where the delayed thaw offers spring-like feeding conditions away from breeding areas. We used satellite remote sensing to estimate surface temperatures of breeding and moulting areas to look for support for this hypothesis at larger spatial scales. Food quality on the moulting grounds was inferred on the basis of the average monthly temperatures on Spitsbergen, Edgeøya and Barentsøya.

\section{Methods and study area}

\section{Satellite telemetry}

Platform Transmitting Terminals (PTTs; Microwave Telemetry Inc., Columbia, MD, USA) were attached to 14 adult male pink-footed geese (seven in March 2003 and seven in March 2004), which had been cannon netted over bait at Vest Stadil Fjord, Denmark ( $56^{\circ} 12^{\prime} \mathrm{N}$; $08^{\circ} 08^{\prime} \mathrm{E}$; see Glahder et al. in press for further details). Six of these geese were tracked through to autumn migration. Five of the PTTs were 30-g battery powered units (for individual birds A2F, A4T, A4Z and A5E in 2003 and B6K in 2004) and one was a 45-g solar powered unit (bird ClT in 2004). All the transmitters were mounted on the backs of the birds with glue. In addition, they were secured either with knicker elastic harnesses (Glahder et al. 1997) or, in the case of the solar powered unit, with Teflon straps (R. Malecki, pers. comm.). The transmitters and harnesses constituted $1.3 \%$ (in the case of the 30-g PTTs) and 1.7\% (in the case of the 45-g PTT) of the body weights of the birds (average $2871 \mathrm{~g}, \mathrm{SD}=172 \mathrm{~g}, n=14$ ). The 30 -g transmitters were programmed to transmit for $8 \mathrm{~h}$ and during three different periods to "rest" for $15 \mathrm{~h}$ (79 cycles, from about 1 April to 15 June), $159 \mathrm{~h}$ (11 cycles, from about 16 June to 31 August) or $111 \mathrm{~h}$ (until the battery power ran out). With a typical battery lifetime of $750 \mathrm{~h}$ estimated by microwave telemetry we expected our programmed PTTs to transmit until at least late September of the same year. The solar powered PTT was programmed to transmit for $10 \mathrm{~h}$ and to "rest" for $21 \mathrm{~h}$. Details about the PTT transmissions, receptions, position calculations and accuracy are given in Fox et al. (2003). Positions were filtered using an Argos Filter V5.0 SAS program developed by Dave Douglas (USGS, Alaska Science Center, Anchorage, AK, USA). With this program we excluded locations in the poorest quality classes (<class 1 ) unless their locations were within $5 \mathrm{~km}$ of a previous or subsequent location.

\section{The areas, duration and timing of summering and staging}

For each staging area of a tracked bird, 50\% dispersion ranges were calculated as harmonic means (with outliers removed and cell sizes optimized; Dixon \& Chapman 1980) using Range Manager (1998 Data Solutions; a MapInfo Professional application, http://solutionsgroup. tripod.com). The size of the dispersion range is a function of (1) the movements of the goose and (2) the position inaccuracy, i.e. the difference between the true location and the position derived from the calculated location. We defined a summering area as a potential breeding area. A staging area was described by at least eight valid positions, and if more than one staging area was used by the goose no overlap was accepted between 50\% dispersion ranges. A moulting area was defined as a particular "staging" area if the tagged goose remained there for a minimum of 25 consecutive days (the average flightless period of nine goose species according to Hohman et al. 1992), during most of July, when non-breeding pinkfooted geese are considered to be flightless (Madsen et al. 1984). 
Table 1 Summering and moulting sites for satellite-tagged pink-footed geese. Mean June and July temperatures are shown for the two sets of areas. The number of $1-\mathrm{km}$ squares (pixels) inside each $50 \%$ dispersion range is given for each of the two types of sites. The summering and moulting periods are minimum periods as defined in the text, and dates are given in day and month (e.g., $27 / 5$ is 27 May). The migration distance is the great circle route in kilometres from west (W) to east (E) between the two areas.

\begin{tabular}{|c|c|c|c|c|c|c|c|c|c|c|c|}
\hline $\begin{array}{l}\text { Goose } \\
\text { ID }\end{array}$ & $\begin{array}{l}\text { Dist. W-E } \\
(\mathrm{km})\end{array}$ & $\begin{array}{l}\text { Summering } \\
\text { site dates }\end{array}$ & $\begin{array}{l}\text { No. } \\
\text { pixels }\end{array}$ & $\begin{array}{l}\text { Position } \\
{ }^{\circ} \mathrm{N},{ }^{\circ} \mathrm{E}\end{array}$ & $\begin{array}{l}\text { Mean June } \\
\text { temp. }\left({ }^{\circ} \mathrm{C}\right)\end{array}$ & $\begin{array}{l}\text { Mean July } \\
\text { temp. }\left({ }^{\circ} \mathrm{C}\right)\end{array}$ & $\begin{array}{l}\text { Moulting } \\
\text { site dates }\end{array}$ & $\begin{array}{l}\text { No. } \\
\text { pixels }\end{array}$ & $\begin{array}{l}\text { Position } \\
{ }^{\circ} \mathrm{N},{ }^{\circ} \mathrm{E}\end{array}$ & $\begin{array}{l}\text { Mean June } \\
\text { temp. }\left({ }^{\circ} \mathrm{C}\right)\end{array}$ & $\begin{array}{l}\text { Mean July } \\
\text { temp. }\left({ }^{\circ} \mathrm{C}\right)\end{array}$ \\
\hline $\mathrm{A} 2 \mathrm{~F}$ & 215 & $27 / 5-11 / 6$ & 98 & $78.7,15.3$ & -1.06 & 11.13 & $02 / 7-30 / 7$ & 55 & $77.5,22.8$ & -0.23 & 4.68 \\
\hline A4T & 180 & $23 / 5-30 / 6$ & 22 & $78.2,13.5$ & 3.70 & 9.55 & $13 / 7-17 / 8$ & 33 & $78.9,20.9$ & -4.70 & 2.16 \\
\hline $\mathrm{A} 4 \mathrm{Z}$ & 162 & $08 / 6-15 / 6$ & 11 & $78.2,17.0$ & 10.0 & 14.54 & $28 / 6-08 / 8$ & 25 & $77.5,22.8$ & 2.40 & 9.72 \\
\hline A5E & 180 & $21 / 5-14 / 6$ & 22 & $78.2,17.4$ & 8.28 & 10.59 & $24 / 6-25 / 8$ & 42 & $79.9,16.8$ & -1.41 & 6.50 \\
\hline $\mathrm{C} 1 \mathrm{~T}$ & 163 & $23 / 5-29 / 6$ & 14 & $77.0,15.4$ & 1.94 & 8.70 & 03/7-11/9 & 48 & $77.5,21.7$ & -0.36 & 4.51 \\
\hline B6K & 251 & $01 / 6-05 / 9^{a}$ & 11 & $78.5,11.0$ & 3.58 & 11.03 & $10.9^{b}$ & $142^{c}$ & $78.2,22.1$ & 1.96 & 5.05 \\
\hline
\end{tabular}

${ }^{\mathrm{a}}$ The goose moulted in the summering area, and ${ }^{\mathrm{b}}$ stayed only briefly on northern Edgeøya before the autumn migration. ${ }^{\mathrm{C}}$ The autumn range of B6K was poorly defined by data from one day only (six positions).

Minimum staging periods were calculated for each location by subtracting the time from the first position from that of the last position. Because of the programmed "resting" periods of $21 \mathrm{~h}$ (solar powered transmitter) and $159 \mathrm{~h}$ (battery powered transmitters) during most of the post-breeding period, the actual staging period could be 42-318 h (about 2-14 days) longer than estimated.

The summering and moulting areas were all located below 100 m a.s.l. (Norwegian Polar Institute 1996), and all were near-shore areas, except for one summering area (river plain, A5E). Most of the summering areas were in the Cassiope tetragona and Dryas octopetala zones of the Mid Arctic vegetation region defined by Rønning (1996). Habitats were tundra, except for one delta area. Most of the moulting areas were in the Papaver dahlianum zone of the High Arctic vegetation region defined by Rønning (1996). The moulting areas were either deltas or tundra with large lakes or lagoons.

\section{Temperature data}

The Moderate Resolution Imaging Spectroradiometer (MODIS) is a remote-sensing instrument on board the TERRA (EOS AM) and AQUA (EOS PM) satellites, providing a range of environmental data at three spatial scales: 250, 500 and $1000 \mathrm{~m}$ (Friedl et al. 2002; Petitcollin \& Vermote 2002). For the present study, the MODll product within the larger MODIS dataset was used to generate information on mean monthly land surface temperatures $\left( \pm 0.5^{\circ} \mathrm{C}\right)$ across the entire Svalbard area (USGS EROS Data Center 2002). These data were imported into ArcGIS version 9.0 and converted to raster format at a $1-\mathrm{km}$ resolution. For each goose staging area, defined by a $50 \%$ dispersion range, average monthly temperatures were calculated for June and July. To calculate differences in mean temperatures between summer- ing sites (areas in western Spitsbergen) and moulting sites (areas mainly in eastern Svalbard), we averaged the mean temperatures on each type of site for five of the geese. The goose B6K was omitted because it moulted at the summering site (Table 1). The two averages that had similar variances (F-test, two-tailed) were tested with a two-tailed Student's $t$-test.

\section{Results}

\section{Movements and staging areas}

Upon arrival to Svalbard in late May, the geese fitted with satellite transmitters moved to summering sites in central, western or northern parts of Spitsbergen (Glahder et al. in press). Five of the six geese left these areas between 11 and 30 June, while the sixth goose (B6K) stayed on the island of Prins Karls Forland until 5 September (Fig. 1; Table 1). All five geese went east and four geese staged at eastern localities until the autumn migration. The average arrival date at the eastern sites was 28 June $(\mathrm{SD}=11$ days, range $=16$ June-13 July). Birds used either one or no staging areas before the moult (Fig. 1). One of the five geese (A5E) stayed on Edgeøya from 16 to 22 June and then proceeded to northern Spitsbergen, where it stayed during the moulting period. The last signal from A5E was received from northern Spitsbergen on 9 September (Fig. 1). On average, the five geese moved $180.0 \mathrm{~km}$ (great circle route, $\mathrm{SD}=21.4 \mathrm{~km}, n=5$ ) from summering to moulting areas; the direction was east with an average summering position of $78.1^{\circ} \mathrm{N}, 15.7^{\circ} \mathrm{E}$ $\left(\mathrm{SD}_{\mathrm{N}}=0.6^{\circ}, \mathrm{SD}_{\mathrm{E}}=1.6^{\circ}, n=5\right)$ and an average moulting position of $78.3^{\circ} \mathrm{N}, 21.0^{\circ} \mathrm{E}\left(\mathrm{SD}_{\mathrm{N}}=1.1^{\circ}, \mathrm{SD}_{\mathrm{E}}=2.5^{\circ}, n=5\right)$. The five geese stayed at a moulting area for an average of 47.2 days ( $\mathrm{SD}=17.8$ days, $n=5$ ) (Table 1 ), and after that period they moved between an average of 1.4 staging 
(a)

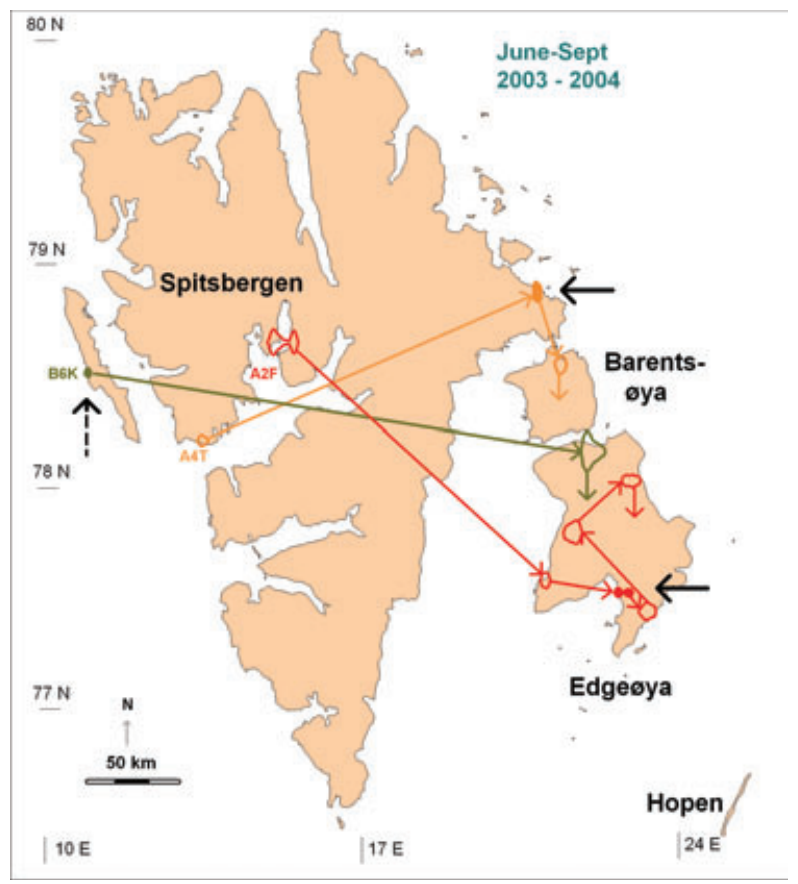

(b)

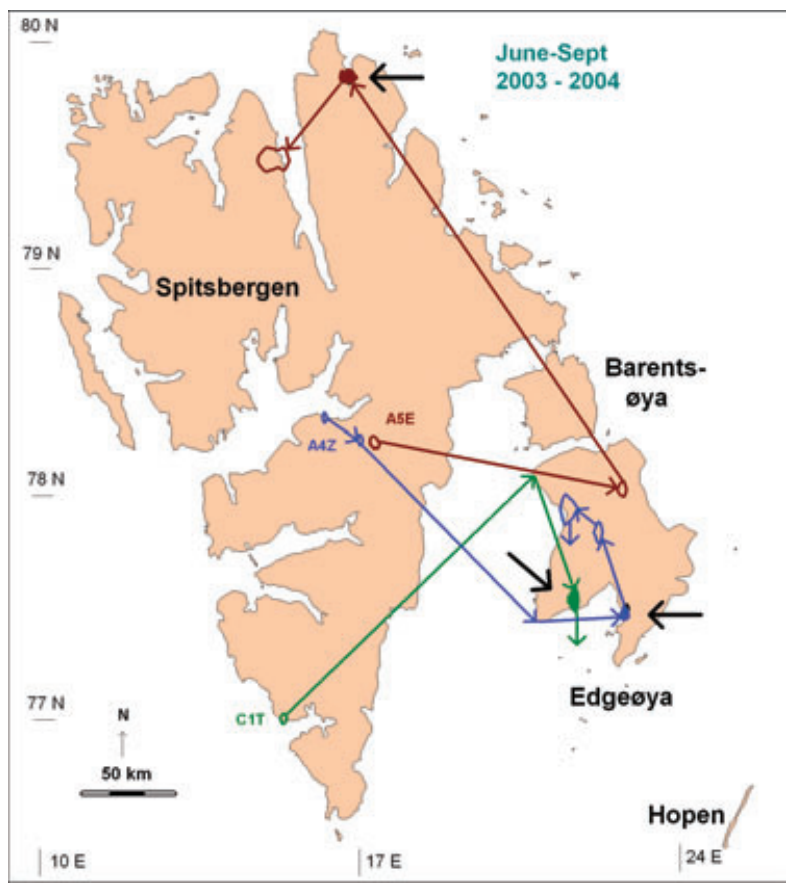

Figure 1 Movements and staging areas of transmitter-tagged pinkfooted geese in Svalbard during the period of June-September in 2003 and 2004. Dispersion ranges (50\%) and movements are shown for six individual geese: (a) A2F, A4T and B6K; and (b) A4Z, A5E and C1T (identifcation numbers indicated at summering sites). Arrows pointing at filled-in dispersion ranges indicate moulting sites. B6K probably moulted on the summering site and it staged only briefly at the post-moulting site on Edgeøya before the autumn migration. areas (range 0-3) before they started their autumn migration. The average departure date from the moulting areas was 18 August ( $\mathrm{SD}=16.5$ days, $n=5$; Table 1 ). B6K went east to stage on Edgeøya for between 1 (minimum) and 9 (maximum) days before its autumn migration. B6K was observed on wintering grounds in the Netherlands; the individual was associated with a female goose but without any juveniles (F. Cottaar, pers. comm.). The date of the last signal transmitted from the geese in Svalbard before the onset of the autumn migration was 11 September ( $\mathrm{SD}=2.2$ days, $n=6$, variation: 9-15 September). The dataset comprised in total 1362 positions (average $=$ 227, $\mathrm{SD}=161, n=6$, variation: 107-507).

\section{Mean temperatures at staging areas}

The differences in mean temperatures between western Spitsbergen (summering sites) and eastern Svalbard (moulting sites on Edgeøya and Barentsøya and in eastern and northern Spitsbergen) were illustrated by calculating mean temperatures at 50\% dispersion ranges during June and July (Table 1; Figs 2, 3). In June, the mean temperature in the western areas was $4.6^{\circ} \mathrm{C}\left(\mathrm{SD}=4.5^{\circ} \mathrm{C}, n=5\right)$ and $-0.9^{\circ} \mathrm{C}\left(\mathrm{SD}=2.6^{\circ} \mathrm{C}, n=5\right)$ in the eastern areas-a significant difference of $5.4^{\circ} \mathrm{C}$ (Student's $t$-test, $P=0.05$, $t=2.39, d f=8)$. In July, the mean temperature in the western areas was $10.9^{\circ} \mathrm{C}\left(\mathrm{SD}=2.2^{\circ} \mathrm{C}, n=5\right)$ and $5.5^{\circ} \mathrm{C}$ $\left(\mathrm{SD}=2.8^{\circ} \mathrm{C}, n=5\right)$ in the eastern areas, a significant difference of $5.4^{\circ} \mathrm{C}$ (Student's $t$-test, $P=0.01, t=3.39$, $d f=8)$. The difference of $0.9^{\circ} \mathrm{C}\left(5.4-4.6^{\circ} \mathrm{C}\right)$ between mean July temperatures in the eastern areas and mean June temperatures in the western areas was not significantly different (Student's $t$-test, $P>0.1, t=0.38, d f=8$ ).

\section{Discussion}

To our knowledge, this paper is the first to document an eastward moult migration in Northern Hemisphere goose populations. Pink-footed geese arriving in Svalbard in late May need good foraging conditions to replenish body reserves lost during the ca. $1100 \mathrm{~km}$ migration-much of it over the open sea-prior to the initiation of egg-laying. In our study, pink-footed geese arriving in Svalbard in mid-May encountered air temperatures below $0^{\circ} \mathrm{C}$, and were therefore almost entirely restricted to feeding on above-ground grass litter from the previous year (Fox et al. in press). Following initial staging for about one week, the geese moved to summering sites in western Spitsbergen (Glahder et al. in press). The areas used by pink-footed geese fitted with PTTs had mean June temperatures of $4-5^{\circ} \mathrm{C}$. Temperatures above $0^{\circ} \mathrm{C}$ spur the growth of fresh shoots of tundra plants, and the thawing ground gives the geese access to below-ground plant storage organs. 


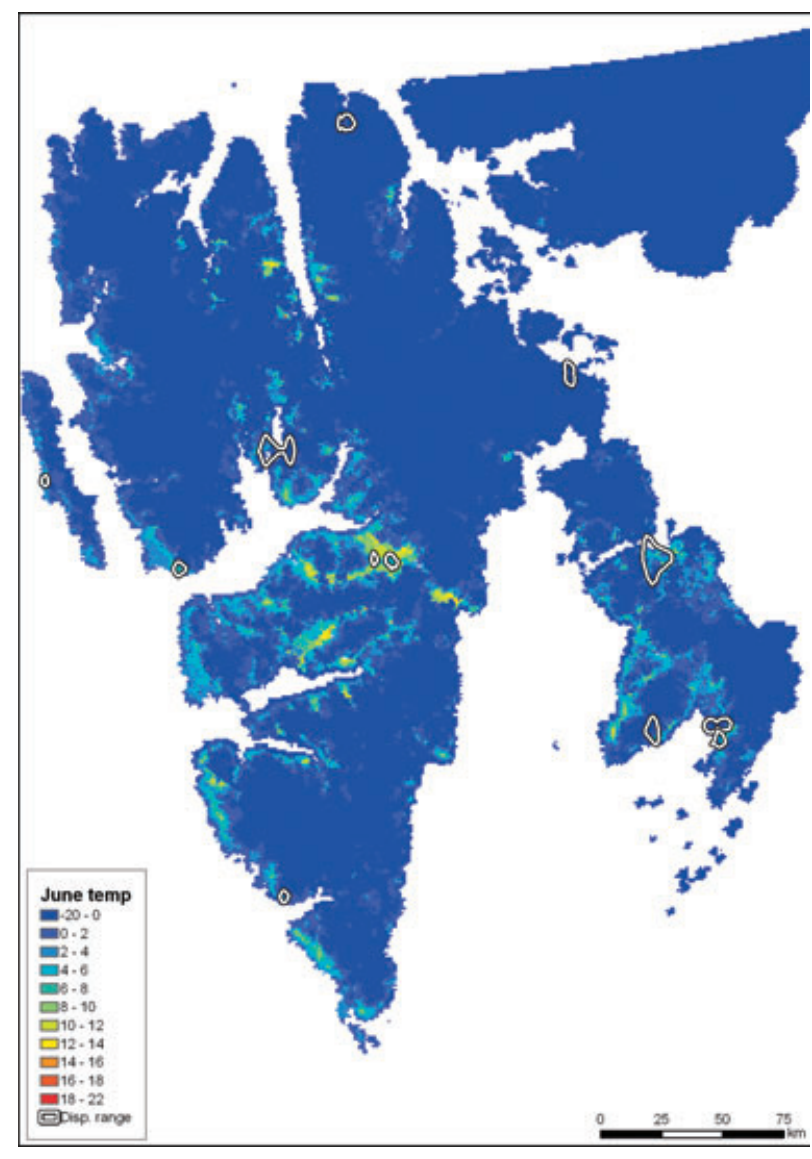

Figure 2 Mean June temperatures $\left({ }^{\circ} \mathrm{C}\right)$ on Svalbard in $1-\mathrm{km}$ squares. Temperatures are given in $2^{\circ} \mathrm{C}$ intervals except for temperatures below $0^{\circ} \mathrm{C}$ and above $18^{\circ} \mathrm{C}$, each of which are pooled in one category. The dispersion ranges (50\%) (Disp. range) covering summering and moulting sites are shown for the six geese attached with Platform Transmitting Terminals (PTTs) (see Fig. 1).

During the second part of June, five of the six pinkfooted geese tagged with PTTs moved about $200 \mathrm{~km}$ eastwards, while the sixth goose stayed at the summering site until shortly before the autumn migration. As the pinkfooted goose moults remiges during most of July (Madsen et al. 1984) and the five geese moved out of their summering sites prior to that period, we interpret this movement as a moult migration of either failed or nonbreeding geese. This interpretation is supported by the fact that the average staging period lasted more than 25 days and covered most of July. The mean July temperature in the moulting areas increased from below the freezing point in June to $5.5^{\circ} \mathrm{C}$ in July. This means that the geese are likely to have encountered soil conditions and plant growth stages (and hence forage conditions) similar to those experienced at the western summering sites in June. With the relatively modest energy expendi-

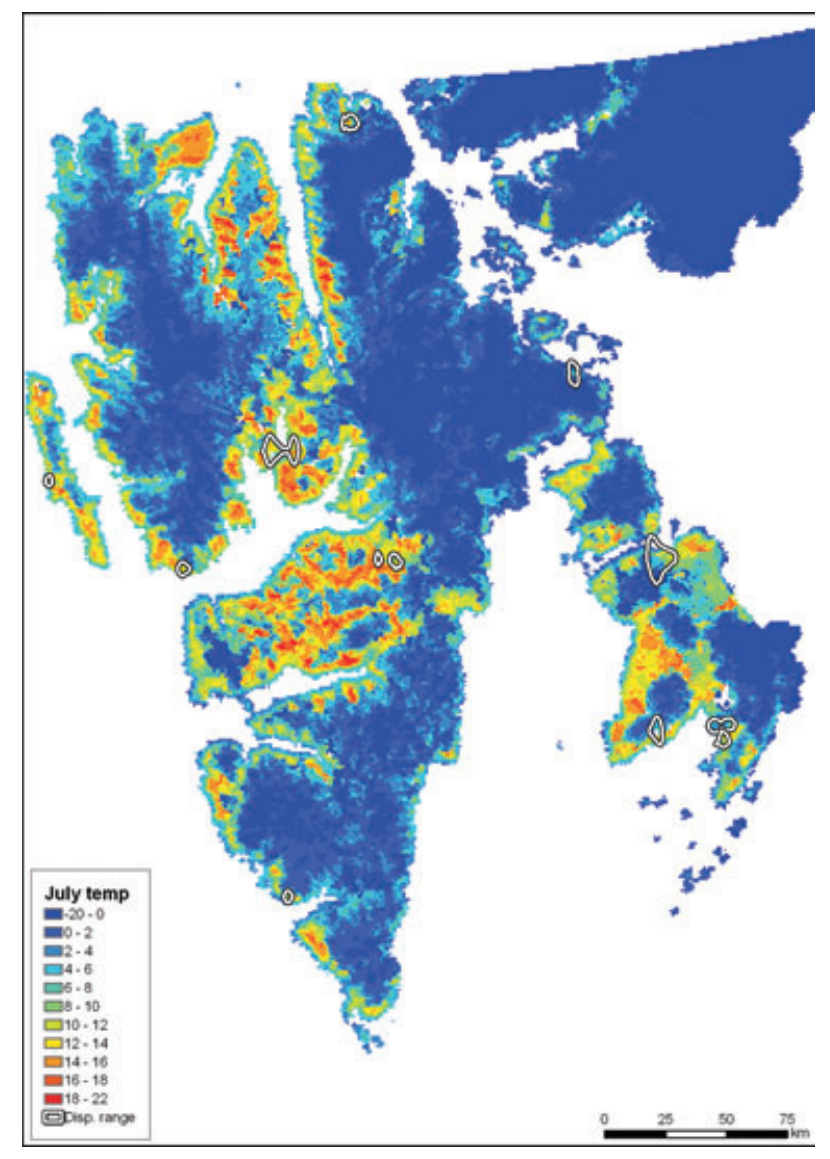

Figure 3 Mean July temperatures $\left({ }^{\circ} \mathrm{C}\right)$ on Svalbard in 1-km squares. Temperatures are given in $2^{\circ} \mathrm{C}$ intervals except for temperatures below $0^{\circ} \mathrm{C}$ and above $18^{\circ} \mathrm{C}$, each of which are pooled in one category. The dispersion ranges (50\%) (Disp. range) covering summering and moulting sites are shown for the six geese attached with Platform Transmitting Terminals (PTTs) (see Fig. 1).

ture of a $200-\mathrm{km}$ flight, the geese regained access to optimal forage conditions with fresh new growth of grasses and sedges. They also gained access to belowground storage organs, although these may not be of main importance in the diet if the feeding behaviour during their moult is similar to that of pink-footed geese in Iceland and Greenland (Madsen \& Mortensen 1987).

The geese moved out of their moulting areas around mid-August to stage at relatively few other areas in Svalbard before the autumn migration. This suggests that exploitation of moulting areas extends through the greater part of the pre-migration fattening period, when energy demands are high. Because the plant growing season begins too late to sustain breeding attempts in these areas, another advantage of using eastern moulting sites is that the moulters meet comparatively little intraspecific competition from breeding geese here. 
Interspecific competition from barnacle geese and brent geese (Branta bernicla) is unlikely because these species are scarce in this part of Svalbard (Madsen et al. 1992; Mehlum 1998). The moulting grounds on Edgeøya and Barentsøya (Fig. 1) have relatively high densities of Svalbard reindeer (Rangifer tarandus platyrhynchus) (Kovacs \& Lydersen 2006), on which the Arctic fox (Alopex lagopus) is highly dependant all year round (Eide 2002). On the other hand, densities of breeding birds are low in these areas so the predation pressure from the foxes is probably relatively low.

\section{Acknowledgements}

We would like to thank Peter Aastrup, National Environmental Research Institute, for his help with transforming the satellite data into the GIS platform for analysis. J.-F. Giroux and an anonymous referee are thanked for their valuable comments on the first version of the paper. The study was performed under the EU 5th framework project FRAGILE (EVK2-2001-00235).

\section{References}

Boertmann D.M. 1994. An annotated checklist to the birds of Greenland. Meddelelser om Gronland, Bioscience 38.

Davis R.A., Jones R.N., MacInnes C.D. \& Pakulak A.J. 1985. Molt migration of large Canada geese on the west coast of Hudson Bay. Wilson Bulletin 97, 296-305.

Dixon K.R. \& Chapman J.A. 1980. Harmonic mean measure of animal activity areas. Ecology 61, 1040-1044.

Eide N.E. 2002. Spatial ecology of Arctic foxes. Relations to resource distribution, and spatiotemporal dynamics in prey abundance. $\mathrm{PhD}$ thesis, Dept. of Biology and Nature Conservation, Agricultural University of Norway/Norwegian Polar Institute.

Ekman S. 1922. Djurvärldens utbredningshistoria på Skandinaviska halvön. (The distribution history of animals on the Scandinavian peninsula.) Stockholm: Bonniers.

Fox A.D., Francis I.S. \& Bergersen E. In press. Diet and habitat use of Svalbard pink-footed geese during arrival and prebreeding periods in Adventdalen. Ardea 94.

Fox A.D., Glahder C.M. \& Walsh A.J. 2003. Spring migration routes and timing of Greenland white-fronted geeseresults from satellite telemetry. Oikos 103, 415-425.

Fox A.D., Madsen J. \& Stroud D.A. 1983. A review of the summer ecology of the Greenland white-fronted goose Anser albifrons flavirostris. Dansk Ornitologisk Forenings Tidsskrift 77, 43-55.

Friedl M.A., McIver D.K., Hodges J.C.F., Zhang X.Y., Muchoney D., Strahler A.H., Woodcock C.E., Gopal S., Schneider A., Cooper A., Baccini A., Gao F. \& Schaaf C. 2002. Global land cover mapping from MODIS: algorithms and early results. Remote Sensing of Environment 83, 287-302.

Glahder C., Fox A.D. \& Walsh A.J. 1997. Effects of fitting dummy satellite transmitters to geese. Wildfowl 48, 88-97.
Glahder C.M., Fox A.D., Hübner C.E., Madsen J. \& Tombre I.H. In press. Pre-nesting site use of satellite transmitter tagged Svalbard pink-footed geese. Ardea 94.

Hochbaum H.A. 1955. Travels and traditions of waterfowl. Minneapolis, University of Minnesota Press.

Hohman W.L., Ankney C.D. \& Gordon D.H. 1992. Ecology and management of postbreeding waterfowl. In B.D.J. Batt et al. (eds.): Ecology and management of breeding waterfowl. Pp. 128189. Minneapolis: University of Minnesota Press.

Kovacs K.M. \& Lydersen C. (eds.) 2006. Birds and mammals of Svalbard. Polarhåndbok 13. Tromsø: Norwegian Polar Institute.

Madsen J., Bregnballe T. \& Hastrup A. 1992. Impact of the Arctic fox Alopex lagopus on nesting success of geese in southwest Svalbard, 1989. Polar Research 11, 35-39.

Madsen J., Kuijken E., Meire P., Cottar F., Haitjema T., Nicolaisen P.I., Bones T. \& Mehlum F. 1999. Pink-footed goose Anser brachyrhynchus: Svalbard. In J. Madsen et al. (eds.): Goose populations of the western Palearctic. A review of status and distribution. Wetlands International Publication 48. Pp. 82-93. Rønde, Denmark: National Environmental Research Institute.

Madsen J. \& Mortensen C.E. 1987. Habitat exploitation and interspecific competition of moulting geese in East Greenland. Ibis 129, 25-44.

Madsen J., Mortensen C.E. \& Boertmann D. 1984. The significance of Jameson Land, East Greenland as moulting and breeding area for geese: results of censuses 1982-84. Dansk Ornitologisk Forenings Tidsskrift 78, 121-131.

Mehlum F. 1998. Areas in Svalbard important for geese during the pre-breeding, breeding and post-breeding periods. In F. Mehlum et al. (eds.): Research on Arctic geese. Proceedings of the Svalbard Goose Symposium, Oslo, Norway, 23-26 September 1997. Norsk Polarinstitutt Skrifter 200. Pp. 41-55. Oslo: Norwegian Polar Institute.

Norwegian Polar Institute 1996. Svalbard 1:250,000. Topographic maps 1 and 2. Oslo: Norwegian Polar Institute.

Petitcollin F. \& Vermote E.F. 2002. Land surface reflectance, emisivity and temperature from MODIS middle and thermal infrared data. Remote Sensing of Environment 83, 112-134.

Raveling D.G. 1970. Dominance and agonistic behaviour of Canada geese in winter. Behaviour 37, 291-319.

Reed E.T., Bêty J., Mainguy J., Gauthier G. \& Giroux J.-F. 2003. Molt migration in relation to breeding success in greater snow geese. Arctic 56, 76-81.

Rønning O.I. 1996. Svalbards flora. (The flora of Svalbard.) Polarhåndbok 9. Oslo: Norwegian Polar Institute.

Salomonsen F. 1968. The moult migration. Wildfowl 19, 524.

USGS EROS Data Center 2002. MODIS reprojection tool user's manual. Dept. of Mathematics and Computer Science, South Dakota School of Mines and Technology.

Whitten K.R. \& Cameron R.D. 1980. Nutrient dynamics of caribou forage on Alaska's Arctic slope. In E. Reimers et al. (eds.): Proceedings of the second international Reindeer/Caribou Symposium. Pp. 159-166. Trondheim: Direktoratet for Vilt og Ferskvannsfisk (Directorate for Fish and Game). 